\title{
The Pathological Alliance
}

\author{
SUMIT GANGULY
}

$\mathrm{F}$ ew of America's bilateral ties have been as fraught as those with Pakistan. Since 1958, when the two countries forged a military pact, the relationship has been based on dubious premises, false expectations, periodic quarrels, and episodic tensions. Apart from a small community of scholars and policy makers, few are aware that it was Pakistan, not the United States, which had avidly courted the other. Deft Pakistani diplomacy, almost immediately after the creation of the state, persuaded the naive administration of Dwight D.

Eisenhower that Pakistan could swiftly emerge as a staunch anticommunist ally. British officials, still smarting from the end of their empire in India and keen on retaining influence in the region, disingenuously encouraged this belief.

Atleast threescholars-MannakalVenkataramani, Ayesha Jalal, and Robert McMahon-have written with authority on the early years of this relationship and the problematic assumptions that undergirded it. Jalal's work, The State of Martial Rule: The Origins of Pakistan's Political Economy of Defense, unlike those of Venkataramani (The American Role in Pakistan, 1947-1958) and McMahon (The Cold War on the Periphery), deals less with the formation of the bilateral alliance and more with the political conditions within Pakistan that proved propitious for the forging of the security relationship. Dennis Kux, a former US Foreign Service officer, in his book The United States and Pakistan, 1947-2000: Disenchanted Allies, provided a largely descriptive (and somewhat potted) account of the relationship. Kux's book, as well as the three others before it, relied almost exclusively on American (and in Jalal's case British) archival sources.

Given the paucity of reliable and up-to-date sources on this long-troubled relationship, Husain

Sumit GANGULY, a Current History contributing editor, is a professor of political science at Indiana University, Bloomington, and a senior fellow at the Foreign Policy Research Institute.
Haqqani's book Magnificent Delusions represents a milestone. Haqqani, a former journalist, served as Pakistani ambassador to the United States from 2008 to 2011, and is currently a professor of international relations at Boston University. He writes with clarity and verve, and has made careful use of recently declassified American archives, combined with his extraordinary grasp of his country's contemporary history and politics. He has produced what is, to date, easily the most candid, readable, and insightful account of the US-Pakistan relation-

ship's evolution.

As the book's title makes clear, this is a tale of mutual and grand delusions. These misapprehensions have been compounded by deeply flawed American expectations of Pakistan and deeply duplicitous Pakistani behavior. It is quite remarkable that Haqqani, who served his country loyally, can write with such painful honesty.

Haggani affirms that Pakistani decision makers successfully deployed the communist bogey from the very genesis of this relationship. He reminds his readers that, despite sounding the tocsin about the possible Soviet penetration of South Asia, Pakistan's leadership was almost completely obsessed with building a formidable military bulwark against its sworn enemy, India. The United States, which had paid scant heed to the region and knew little about it, was soon inveigled into fashioning an important military relationship with Pakistan.

Haqqani shows that despite American military and economic largess, Pakistan's leadership, both military and civilian, has rarely been satisfied. Instead, it has almost always sought more than what the United States was prepared to grant, whether in terms of military, economic, or even diplomatic assistance. A constant Pakistani refrain is that Washington has never quite seen eye to eye with it on matters pertaining to its Indian nemesis. 
Among other issues that have proved to be leitmotifs in the relationship, one is the Pakistani leadership's propensity for mythmaking. In 1965, for example, it assumed that anti-Indian sentiment in Kashmir would translate into support for Pakistan, but that did not happen during a brief war over the disputed territory. Haqqani's discussion of the pathologies of Pakistani decision making during the 1971 crisis that led to Bangladesh's independence is brutally frank. He also shows that after the crisis, instead of engaging in serious introspection about its own egregious errors, the leadership chose to place the blame on Indian perfidy.

Worse still, when faced with adverse developments in the bilateral relationship or confronted with the consequences of flawed choices, the leadership has taken refuge in conspiracy theories. When seeking to ascertain the precise degree of support that the Nixon administration was willing to provide Pakistan at the height of the 1971 crisis, President Zulfikar Ali Bhutto concocted a bizarre tale about a possible plot between Afghanistan and India to pursue the dismemberment of Pakistan.

\section{MUTUAL DELUSION}

Of course, the delusions that have haunted the relationship are by no means one-sided. The United States, which accepted Pakistani claims of a shared anticommunist mission in the 1950s, again fell prey to similar blandishments at the time of the Soviet invasion and occupation of Afghanistan in 1979. Washington backed away from exerting pressure on Islamabad to terminate its nuclear weapons program when General $\mathrm{Zia}$ ul-Haq denied its existence, even though the US interlocutor, General Vernon Walters, concluded that Zia was lying. The United States bought into the Pakistani argument that suitable American military assistance would enable the two allies to dislodge the Soviet Union from Afghanistan. However, Haqqani shows that Zia's central preoccupation remained India and not the Soviet presence in Afghanistan.

The US capacity for self-delusion, Haqqani demonstrates, has even afflicted intelligence collection on Pakistan. When organizing the Afghan resistance, the Defense Intelligence Agency apparently placed great stock in the head of the Pakistani Inter-Services Intelligence Directorate, Lieutenant General Hamid Gul. It was blissfully unaware of Gul's ideological predilections, which were firmly in the Islamist camp and viciously anti-American and anti-Western. His views certainly informed the decision making of the Pakistani military and facilitated the emergence of the Taliban in Afghanistan. In turn, the Taliban provided a safe haven for Al Qaeda.

What is utterly baffling and astonishing is that the relationship, despite its mutually erroneous assumptions and tormented phases, has survived over decades. Periodically the United States has disengaged from Pakistan and even from the region. However, exigent circumstances have repeatedly led to renewed attempts at cooperation. Unfortunately, most Pakistani interlocutors have repeatedly proved disingenuous on multiple fronts. Their American counterparts, in turn, thanks to their eagerness to address their own immediate strategic interests, have chosen to overlook this bad faith.

The unwillingness of both sides to forthrightly confront fundamentally divergent interests has persistently resulted in mutual disillusionment. Haqqani quite correctly suggests that placing the bilateral relationship on a more secure footing will require fundamental changes of behavior on both sides. As he says, "Unless Pakistanis define their national interests differently from how their leaders have for six decades, the US-Pakistan alliance is only a mirage."

Policy makers-both in his homeland and in the United States-may find Haqqani's blunt but accurate assessment discomfiting. But if they ignore his counsel it will be at their own peril.

From the archives of Current History...

"In Kabul today, most Afghans, from illiterate cooks to well-educated civil servants, take it for

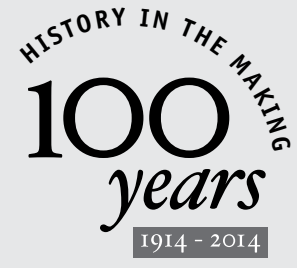
granted that the Taliban are coming back to power. Afghans speak of yet another American betrayal, trading theories on why the United States and the international community have not been serious about combating the Taliban insurgency, stemming the flow of jihadists out of Pakistan, or devoting money and resources sufficient to rebuild the country."

Ahmed Rashid

"Letter from Afghanistan: Are the Taliban Winning?" January 2007 